\title{
三次元複合材料の弾性常数と強度
}

\author{
土方 明躬*, 森 顕 伸**, 福多 健二***
}

(1992 年 1 月 26 日受付)

\section{Elastic Constant and Strength of Three-Dimensional Composite Material}

\author{
A. Hijikata,* A. Mori** and K. Fukuta***
}

(Received January 26, 1992)

Three-dimensional composites were made firstly by orientating fiber bundles in roving or rodlike shape unidirectional composites and secondarily molded with resin. To evaluate the elastic constants and the strength of the 3-D composites, an analytical method was developed adopting the orthogonal anisotropic theory of elasticity. Tensile and compressive tests on orthogonal three axis 3-D CFRP were also made, and the results of elastic constants and initial breaking strength were compared with the theoretical values. The test result showed good agreement with the analytical result. Furthermore, these mechanical properties were evaluated for 3-D composites consisting of 3 to 7 -axis by using the analytical method. As the results, it was found that 7 axis were advantageous to pseudo-isotropic material, and 4 or 5 axis to anisotropic material.

\section{1. 緒}

三次元複合材料は，從来の䅡層複合材料の弱点である 咯間強度の收善が期待され，さらに，強化繊維の軸数を 增やすことによって多軸伈力下で使用できる複合材料と して期待されている.

このような三次元複合材料の機械的特性については, 三次元 3 軸 CFRP についての試験結果が, 福多らほ か1,2)により報告されている. 一方，機械的特性の解析 法については, ロッド状一力向材を直交 3 軸に組織した 複合材料について, Aboudi による弾性常数の解析 ${ }^{3)}$ が ある. また，繊維で構成した三次元多軸複合材料につい て，等価介在物法による八田の解析 ${ }^{4}$ が報告されてい る.しかし，実際の三次元複合材料として製作されてい る，ロービングあるいはロッド状の繊維束を三次元に配

*ー*** (侏スリーディコンポリサーチ（305つくば市

千現 2 丁目 1-6)

Three-D Composites Research Corporation, CB3, TCI, 2-1-6 Sengen, Tsukuba 305, Japan

* 現在, 三菱電機(侏)中央研究所

Now at Central Research Laboratory, Mitsubishi Electric Corporation

** 現在, 三菱電機(制材料研究所

Now at Materials and Electronic Devices Laboratory, Mitsubishi Electric Corporation

*** 研究所長 Research Manager
向した 4 軸以上の複合材料の機械的特性の解析は見あた らない.

$$
\text { そこで，本䖨告では，ロービングあるいはロッド状の }
$$
䋐維束を三次元に配列した複命材料の弹性常数や初期破 断強度を, 三次元直交異方性弾吽:論をるとに解析する方 法を導き，三次元 3 軸 CFRP の試験結果と比較して解

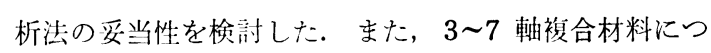
いて, これらの特性を求め, 三次元的に擬等方性を得る 細織や異方吽:を生かした組織構造について検討した。

\section{2. 解 析 法}

\section{1 弾 性常 数}

(1) 口ッド状一方向材の剛性

三次元複合材料を桠成与るロービングあるいはロッド 状の一方向材（以下口ッドと呼ぶ）の主軸 $x, y, z$ 方向 の弾性係数を $E_{x}, E_{y}, E_{z}$ とし, 剪断弾性係数を $G_{y z}$, $G_{z x}, G_{x y}$, 犬゚アソン比を $\nu_{y z}, \nu_{z x}, \nu_{x y}$ とする.

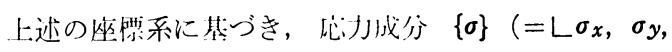

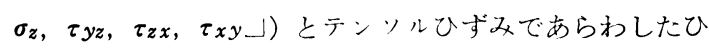
ず久成分 $\{\varepsilon\}\left(=\left\llcorner\varepsilon_{x}, \varepsilon_{y}, \varepsilon_{z}, \gamma_{y z}, \gamma_{z x}, \gamma x y\right\lrcorner\right)$ の関 係は，(1)式となる。

$$
\{\sigma\}=[Q]\{\varepsilon\}
$$

ここに， $[Q]$ は $6 \times 6$ の弾修常数からなるマトリックス

であり，その構成成分 $Q_{i j}(i, j=1 \sim 6)$ を以下に示す. 


$$
\begin{aligned}
& Q_{11}=m E_{x}\left\{1-\left(E_{z} / E_{y}\right) \nu_{y} z^{2}\right\} \\
& Q_{12}=Q_{21}=m E_{y}\left\{\nu_{x} y+\left(E_{z} / E_{y}\right) \nu_{y z} \nu_{z x}\right\} \\
& Q_{13}=Q_{31}=m E_{z}\left(\nu_{z x}+\nu_{x y} \nu_{y z}\right) \\
& Q_{22}=m E_{y}\left\{1-\left(E_{z} / E_{x}\right) \nu_{z} x^{2}\right\} \\
& Q_{23}=Q_{32}=m E_{z}\left\{\nu_{y z}+\left(E_{y} / E_{x}\right) \nu_{x} \nu_{z x}\right\} \\
& Q_{33}=m E_{z}\left\{1-\left(E_{y} / E_{x}\right) \nu_{x y}\right\} \\
& Q_{44}=2 G_{y z} \\
& Q_{55}=2 G_{z x} \\
& Q_{66}=2 G_{x y} \\
& m=1 /\left\{1-\left(E_{z} / E_{y}\right) \nu_{y z} z^{2}-\left(E_{z} / E_{x}\right) \nu_{z x^{2}}\right. \\
& \left.-\left(E_{y} / E_{x}\right) \nu_{x} y^{2}-2\left(E_{z} / E_{x}\right) \nu_{y z} \nu_{z x} \nu_{x y}\right\}
\end{aligned}
$$

(2) 斜交軸系の剛性

いま, Fig.1 に示すように，口ッドの主軸 $x, y, z$ と 異なる直交軸 $X^{\prime}, Y^{\prime}, Z^{\prime}$ 方向に荷重が加わる場合を考 える.

$X^{\prime} ， Y^{\prime} ， Z^{\prime}$ 軸で定義される応力ベタトルを $\left\{\sigma^{\prime}\right\}$, ひ ずみベタトルを $\left\{\varepsilon^{\prime}\right\}$ とし $x, y, z$ 方向の応力を $\{\sigma\}$, ひずみを $\{\varepsilon\}$ とするとき，

$$
\begin{aligned}
& \left\{\sigma^{\prime}\right\}=[T]\{\sigma\} \\
& \left\{\varepsilon^{\prime}\right\}=[T]\{\varepsilon\}
\end{aligned}
$$

[T] は, (5)式で求まる座標変換マトリックスである。 $[T]=$

$\left(\begin{array}{cccccc}l_{1}^{2} & m_{1}{ }^{2} & n_{1}{ }^{2} & 2 m_{1} n_{1} & 2 l_{1} n_{1} & 2 l_{1} m_{1} \\ l_{2}{ }^{2} & m_{2}{ }^{2} & n_{2}{ }^{2} & 2 m_{2} 2_{2} & 2 l_{2} n_{2} & 2 l_{2} m_{2} \\ l_{3}^{2} & m_{3}{ }^{2} & n_{3}{ }^{2} & 2 m_{3} n_{3} & 2 l_{3} n_{3} & 2 l_{3} m_{3} \\ l_{2} l_{3} & m_{2} m_{3} & n_{2} n_{3} & \left(m_{2} n_{3}+n_{2} m_{3}\right) & \left(l_{2} n_{3}+n_{2} l_{3}\right) & \left(l_{2} m_{3}+m_{2} l_{3}\right) \\ l_{1} l_{3} & m_{1} m_{3} & n_{1} n_{3} & \left(m_{1} n_{3}+n_{1} m_{3}\right) & \left(l_{1} n_{3}+n_{1} l_{3}\right) & \left(l_{1} m_{3}+m_{1} l_{3}\right) \\ l_{1} l_{2} & m_{1} m_{2} & n_{1} n_{2} & \left(m_{1} n_{2}+n_{1} m_{2}\right) & \left(l_{1} n_{2}+n_{1} l_{2}\right) & \left(l_{1} m_{2}+m_{1} l_{2}\right)\end{array}\right)$

ここに, $l_{1}, m_{1}, n_{1}$ はそそれぞれ， $X^{\prime}$ 軸の $x, y, z$ 軸に 刘する方向余弦， $l_{2} ， m_{2}, n_{2}$ はそれぞれ $Y^{\prime}$ 軸の $x, y$, $z$ 軸に対する方向余弦, $l_{3}, m_{3}, n_{3}$ はそれぞれ $Z^{\prime}$ 軸の $x, y, z$ 軸に対する方向余弦である.

$$
\begin{array}{r}
\text { (3) 式に(1)式, (4) 式を代入して, } \\
\left\{\sigma^{\prime}\right\}=[T][Q][T]^{-1}\left\{\varepsilon^{\prime}\right\}
\end{array}
$$

となる。

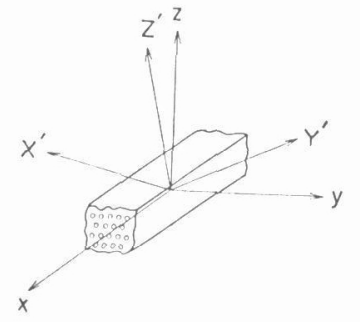

Fig.1 Oblique coordinates of rod.

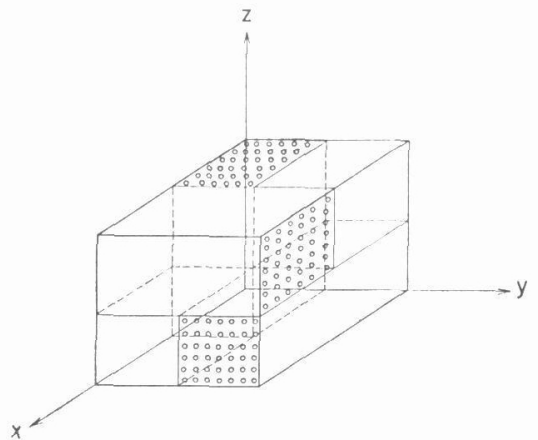

Fig. 2 Unit element of 3-D 3-axis composites.

$$
\left[Q^{\prime}\right]=[T][Q][T]^{-1}
$$

と置くことにより，

$$
\left\{\sigma^{\prime}\right\}=\left[Q^{\prime}\right]\left\{\varepsilon^{\prime}\right\}
$$

在得る。

(3) 三次元多軸複合材料の剛性:

三次元多軸複合材料は，ロッドの配列がある一定の形 をもった监位要素の連続とみることがでさる，例えば直 交 3 軸の単位要溸は Fig. 2 のようになる。

この単位要素内の複数のロッドおよびロッド間の陵間 に充垻されたマトリックス部を，それぞれ引数 $k(=1$, $2,3, \cdots, n)$ により区别与る。 これら各構成部材の $\mathrm{X}^{\prime}$, $Y^{\prime}, Z^{\prime}$ 少向の応力とでずみ坴 $\left\{\sigma^{\prime}\right\}_{k},\left\{\varepsilon^{\prime}\right\}_{k}$ とし, 単位

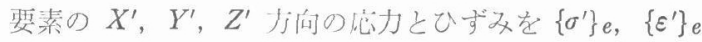
とする.

この単位要素の応力やひずみと, 単位要素内の各榗成 部材の地やひずみの関係を求めるため, 次の仮定を特 $<$.

単位要素のひずみエネルギーと単位要素内の各棈成部 材のひずみエネルギーの和が等しいとして，

$$
\begin{aligned}
& \left\{\sigma^{\prime}\right\}_{e}\left\{\varepsilon^{\prime}\right\}_{e} V / 2 \\
& =\sum_{k=1}^{n}\left\{\sigma^{\prime}\right\}_{k}\left\{\varepsilon^{\prime}\right\}_{k} V_{k} / 2
\end{aligned}
$$

単位要素のひずみと各構成部材のひずみが等しいとし $\tau$,

$$
\left\{\varepsilon^{\prime}\right\}_{e}=\left\{\varepsilon^{\prime}\right\}_{k}
$$

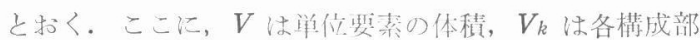
材の体秘である。

このような作迁をおくことにより，（7）式と（8)式よ り,

$$
\left\{\sigma^{\prime}\right\}_{e}=\sum_{k=1}^{n}\left\{\sigma^{\prime}\right\}_{k} V_{k} / V
$$

(6)式，(8)式を(9)式に代人して, 


$$
\begin{gathered}
\left\{\sigma^{\prime}\right\}_{e}=\left(\sum_{k=1}^{n}\left[Q^{\prime}\right]_{k} V_{k} / V\right)\left\{\varepsilon^{\prime}\right\}_{e} \\
{\left[Q^{\prime}\right]_{e}=\left(\sum_{k=1}^{n}\left[Q^{\prime}\right]_{k} V_{k} / V\right)}
\end{gathered}
$$

と置くと,

$$
\begin{aligned}
\left\{\sigma^{\prime}\right\}_{e} & =\left[Q^{\prime}\right]_{e}\left\{\varepsilon^{\prime}\right\}_{e} \\
\left\{\varepsilon^{\prime}\right\}_{e} & =\left[Q^{\prime}\right]_{e}^{-1}\left\{\sigma^{\prime}\right\}_{e} \\
& =\left[C^{\prime}\right]_{e}\left\{\sigma^{\prime}\right\}_{e}
\end{aligned}
$$

となる。

したがって, $\left[Q^{\prime}\right] e,\left[C^{\prime}\right] e$ が, それぞれ, 三次元多軸 複合材料の斜交軸系の剛性マトリックス, コンプライア ンスマトリックスである.

これより, 三次元複合材料の $X^{\prime}, Y^{\prime}, Z^{\prime}$ 方向の弾性 常数は次式で求まる.

$$
\begin{aligned}
& E_{X^{\prime}}=1 / C^{\prime}{ }_{11 e} \\
& E_{Y^{\prime}}=1 / C^{\prime}{ }_{22 e} \\
& E_{Z^{\prime}}=1 / C^{\prime}{ }_{33 e} \\
& G_{Y^{\prime} Z^{\prime}}=1 /\left(2 C^{\prime}{ }_{44 e}\right) \\
& G_{Z^{\prime} X^{\prime}}=1 /\left(2 C^{\prime}{ }_{55 e}\right) \\
& G_{X^{\prime} Y^{\prime}}=1 /\left(2 C^{\prime}{ }_{66 e}\right) \\
& \nu_{X^{\prime} Y^{\prime}}=-C^{\prime}{ }_{21 e} / C^{\prime}{ }_{11 e} \\
& \nu_{Y^{\prime} Z^{\prime}}=-C^{\prime}{ }_{32 e} / C^{\prime}{ }_{22 e} \\
& \nu_{Z^{\prime} X^{\prime}}=-C^{\prime}{ }_{31 e} / C^{\prime}{ }_{11 e}
\end{aligned}
$$

ここに, $C^{\prime}{ }_{i j e}$ は $\left[C^{\prime}\right]_{e}$ の $i j$ 成分の值である.

\section{2 初期破断強さ}

(1) 単位要素内の各部材の応力とひずみ

三次元多軸複合材料に，任意の力向に $\left\{\sigma^{\prime}\right\}_{e}$ の応力を 加えたときのひずみ $\left\{\boldsymbol{\varepsilon}^{\prime}\right\}_{e}$ は，（12）式で求まる，この $\left\{\varepsilon^{\prime}\right\}_{e}$ に対応する単位要素内の各部材の主軸方向のひず み $\{\varepsilon\}_{k}$ は, (4)式より,

$$
\{\varepsilon\}_{k}=[T]_{k}-1\left\{\varepsilon^{\prime}\right\}_{e}
$$

である.

$\{\varepsilon\}_{k}$ による各部材の応力 $\{\sigma\}_{k}$ は，

$$
\{\sigma\}_{k}=[Q]_{k}\{\varepsilon\}_{k}
$$

であるから，

$$
\{\sigma\}_{k}=[Q]_{k}[T]_{k}-1\left[Q^{\prime}\right]^{-1}\left\{\sigma^{\prime}\right\}_{e}
$$

また，各部材のひずみ $\{\varepsilon\}_{k}$ は，

$$
\{\varepsilon\}_{k}=[T]_{k}-1\left[Q^{\prime}\right] e^{-1}\left\{\sigma^{\prime}\right\}_{e}
$$

となる。

（2）初期破断強さ

三次元多軸複合材料に任意の方向に荷重が加わったと き, 構成部材のいずれかが最初に破壊したときを初期破 断強さとする.

複合材の破壞基準には, 数種の基準が提案されている が，ここでは，最大応力説をとることとする．
任意の方向の応力 $\left\{\sigma^{\prime}\right\}_{e}$ に対する各部材の応力 $\{\sigma\}_{k}$ は(14)式で求まるから, 最大応力説に対しては, この $\{\sigma\}_{k}$ と各部材の強度とを比較することにより初期破率 強さが求まる。

\section{3 軸複合材料の弾性常数と強度}

前記の解析法の妥当性を検討するため, 炭素繊維/エ ポキシ樹脂からなる三次元直交 3 軸複合材料の材料試験 を行い, 弾性常数と初期破断強さの試験結果を解析結果 と比較した。

\section{1 供試材料と試験片}

$12 \mathrm{~K} \times 2$ の炭素繊維（トレカ T300）を自動織機5)で直 交 3 軸に製織し，これにエポキシ樹脂を真空含浸注形し た. 樹脂はビスフェノール $\mathrm{F}$ 型エポキシ樹脂十酸無水系 硬化剤である，成形品の寸法は $35 \times 35 \times 500 \mathrm{~mm}$ で，そ の長手方向（Fig. 2 の $\boldsymbol{z}$ 軸方向）の繊維体積含有率 $V_{\mathrm{f}}$ は 0.156 であり，他の 2 軸方向の $V_{\mathrm{f}}$ はともに 0.127 であった。 したがって，全体の $V_{\mathrm{f}}$ はこれらの和の 0.41 である。

試験片形状を Fig. $3(\mathrm{a})(\mathrm{b})$ に示す。 引張り試験片(a)は 成形品の長手力向に採取した。この方向を $0^{\circ}$ 方向と呼 ぶ. 压繀試験版 (b) は, $0^{\circ}$ 万向之 $45^{\circ}$ 万向の 2 種類あ り, 後者は Fig. 2 の $z$ 軸と $y$ 軸の面内で $z$ 軸と $45^{\circ}$ を なす力向である。

\section{2 試験と結果}

引張りと压縮試験は容量 10 トンのインストロン試験 機で行い，試験は各試験片とも6本について行った。試 験片の絎横力向ひずみはゲージ長 $6 \mathrm{~mm}$ のひずみゲージ で測定して，弾性係数とポアソン比を求めた。な牧，ゲ

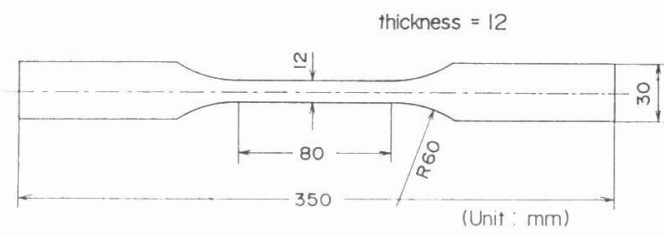

(a) Tensile test specimen.

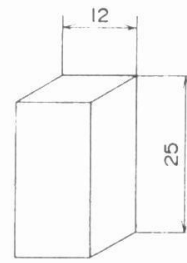

(b) Compression test specimen.

Fig. 3 Dimensions of the test specimen. 
ージ貼布面でのロッド間ピッチは $2.4 \sim 3.0 \mathrm{~mm}$ であり, ゲージ長さは $0^{\circ}$ 万向試験片で約 2 ピッチ, $45^{\circ}$ 方向試 験片では約 1.4 ピッチに相当する. また，クロスヘッド にストロークを変位とする荷重一変位 $(P-\delta)$ 線网を描か せた。

$0^{\circ}$ 万向引張りと圧縮および $45^{\circ}$ 万向圧䌦試験に括け る $P-\delta$ 線図の代表例を Fig. 4 に示寸。図示のと拈り, $0^{\circ}$ 方向引張りでは破断までほ弾性的な挙動を示し, $0^{\circ}$ 方向之 $45^{\circ}$ 方向圧縮では, 弾性域 (I) から大変形领 域（III）への遷移領域（II）が認められる変形举動を示 した。

破断後あるいは領域（III）で除荷した試験片断面の顕 微鏡観察から， $0^{\circ}$ 方向引張りでは繸方向ロッドの引張 り破断が強度を支配しており，0方向圧縮の領域（III） の変形は縦方向ロッドにキンクが生成したことによるも

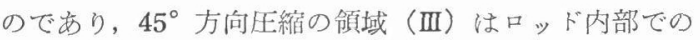
ロッドの剪断すべりに起因した変形であることを確認し た。領域（II）では,これらの破壊が徐々に進行してい る過程と判断される.

そこで，本論文では，この領域（II）飞初期破断強さ がくるように，降伏点が明瞭に現れない材料の耐力を参 考にして，P- $\delta$ 線図に拈ける $0.2 \%$ オフセットひず灰 $(\delta / L=0.002$, こと, $L$ は引張り試験片の平行部長さ あるいは压縮試験片の縦方向長さ) と扣ける応力を初期 破断強さとした. Fig.4 に0.2\%オフセットひずみに相 当する線を点線で示したが，上記の初期破断強さは領域 (II) にある.

以上の方法で求めた弾性係数 $E_{x^{\prime}}$, ポアソン比 $\nu_{X^{\prime} Y^{\prime}}$,

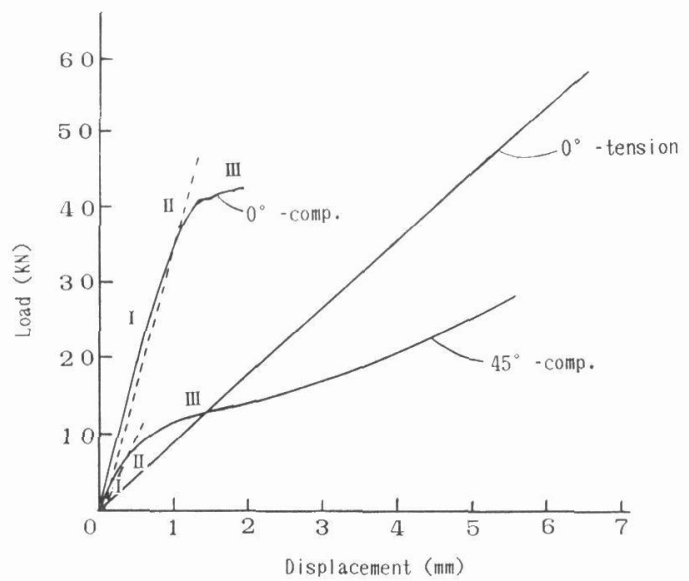

Fig. 4 Load-displacement curve of the tension and compression test.
Table 1 Test results.

\begin{tabular}{cccccc}
\hline & & \multicolumn{2}{c}{$0^{\circ}$ direction } & \multicolumn{2}{c}{$45^{\circ}$ direction } \\
\cline { 3 - 6 } & & Mean (std. dev.) & Mean (std. dev.) \\
\hline$E_{x^{\prime}}$ & tensile & 40.3 & $(2.6)$ & & \\
$(\mathrm{GPa})$ & comp. & 36.0 & $(2.7)$ & 8.2 & $(0.78)$ \\
\hline$\nu_{X^{\prime} Y^{\prime}}$ & tensile & 0.14 & $(0.022)$ & & \\
& comp. & 0.12 & $(0.021)$ & 0.67 & $(0.034)$ \\
\hline$\sigma_{B}$ & tensile & 393 & $(30)$ & & \\
$(\mathrm{MPa})$ & comp. & 296 & $(51)$ & 215 & $(23)$ \\
\hline$\sigma_{0.2}$ & tensile & & & & \\
$(\mathrm{MPa})$ & comp. & 249 & $(19)$ & 70 & $(13)$ \\
\hline
\end{tabular}

初期破断強さ $\sigma_{0.2}$ および破断強さ $\sigma_{B}$ の試験結果を

Table 1 に示す. 同表には六つの試験值の平均と標準偏 差を示した。

\section{3 試験結果と解析結果の比較}

（1）解析に用いた構成材料の特性

解析に用いたロッドとマトリックスの弾性常数と強度 を Table 2 に示す. 同表に示したロッドの弾性常数 は，その構成材料である炭素繊維とさポキシ樹脂の弾性 常数より, Hashin の方法6) で求めた。炭素繊維とエポ キシ樹脂の弾性常数は，つぎの值》を用いた。

炭素繊維; $E_{L}=220 \mathrm{GPa}, E_{T}=20 \mathrm{GPa}, G_{L T}=40 \mathrm{GPa}$, $\nu_{L}=0.31, \nu_{T}=0.33$

(添字 $L$ は綫維の長手方向, $T$ は直角方向を示す)

マトリックス; $E=3.4 \mathrm{GPa}, \nu=0.38$

Table 2 Elastic constants and strength of the rod and matrix of the test specimen.

\begin{tabular}{|c|c|c|}
\hline & $\begin{array}{l}\text { Elastic } \\
\text { constants } \\
(\mathrm{GPa})\end{array}$ & $\begin{array}{l}\text { Strength } \\
(\mathrm{MPa})\end{array}$ \\
\hline \multirow[t]{2}{*}{ Matrix } & $E=3.4$ & tensile strength $=91$ \\
\hline & $\nu=0.38$ & shear strength $=53$ \\
\hline \multirow[t]{2}{*}{ Rod } & $E_{x}=121$ & $\begin{array}{l}\text { axial tens. strength } \\
=1168\end{array}$ \\
\hline & $E_{y}=E_{z}=8.2$ & $\begin{array}{l}\text { comp. strength } \\
\qquad=751\end{array}$ \\
\hline \multirow[t]{4}{*}{$\left(V_{\mathrm{f}}=0.55\right)$} & $G_{x y}=G_{z x}=3.8$ & $\begin{array}{l}\text { shear strength } \\
=53\end{array}$ \\
\hline & $G_{y z}=2.7$ & trans. tens. strength $=91$ \\
\hline & $\nu_{x y}=\nu_{z x}=0.34$ & $\begin{array}{l}\text { comp. strength } \\
\qquad=91\end{array}$ \\
\hline & $\nu y z=0.50$ & $\begin{array}{l}\text { shear strength } \\
\qquad=53\end{array}$ \\
\hline
\end{tabular}


エポキシ樹脂の強度は別途行った材料試験值とした. ロッドの軸方向の強度特性は, $V_{\mathrm{f}}=0.7$ のとさの引张り 強さを $1500 \mathrm{MPa}$ とし，供試ロッドの $V_{\mathrm{f}}=0.55$ に拉 ける引張り・压縮強さをTsai の方法7)で推定した值と したまた，ロッドの直角方向の強度や剪断強度はエポ キシ樹脂のそれらと等しいとした.

(2) 弾性常数

上記の值を用いて前述の方法で計算した弾性常数とポ アソン比を Fig.5 に示す. 同図には Table 1 の試験結 果を作記した。図から明らかなよらに, 試験値と計算值 は浪淁している. 3.2 項に述べたよらに, ひずみゲ ージの長さがロッド配列のピッチに較ぺて十分大きくな いので, 複合組織の平均化したひずみを测定し得ている かどらかの疑問はあるが，試験值のばらつきは比較的小 さく，との影響は小さいと判断される.

(3) 初期破断強さ

Fig. 6 に初期破断強さの計算結果を試験結果とともに 示す. Fig. 6 の計算結果には, 最大応力説で求められた 破断部材とその応力形態を示した. これらは，3.2 項に 述べた試験片で観察された破断部材やその形態と一致し ている. また，試験值は計算値と比較的よく一致してい る.

部算に用いた構成部材の弾性常数や强度が 3.3. (1) に 述べたような仮定值であるため, 解析法の奚当性を論じ

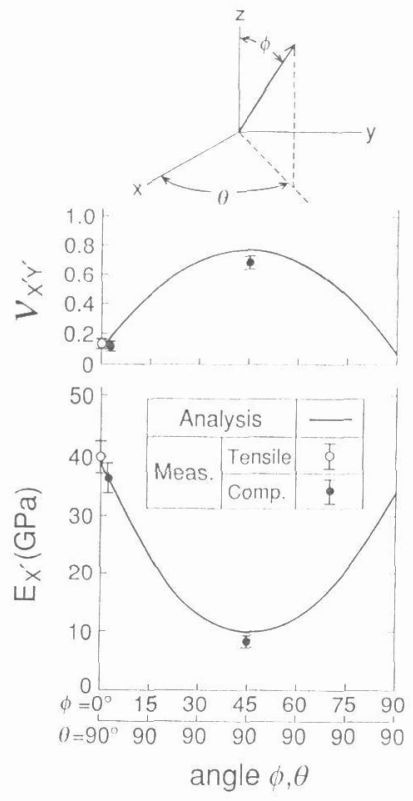

Fig. 5 Experimental and calculated results of $E_{x^{\prime}}$ and $\nu_{x^{\prime} y^{\prime}}$.
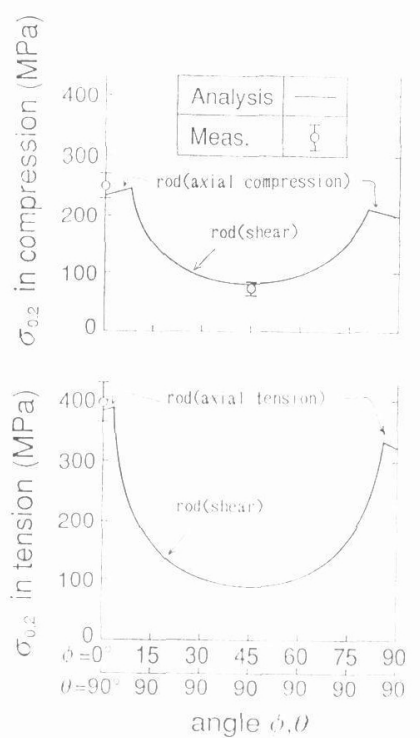

Fig.6 Experimental and calculated results of initial breaking strength in tension and compression.

るには問題はあるが, 以上の結果より, 本解析法が三次 元多軸複合材料の特性の近似的な值を知るための手段と しては付効であると考学られる。

\section{4 7 軸複合材料の弾性常数と強度}

三次元多軸複合材料の組織構成には多くのバリエーシ ョンが考えられるが，ここで解析の対象にした 4〜7 軸 の繊維配列は别報8)に述ベたものと同じとし，単位要素 の $x, y, z$ 軸の寸法比は $1: 1: 1$, ロッドの $V_{\mathrm{f}}$ は 0.7 とした. 使用した炭素瀻維は 3 軸複合材料と同様に T300であり, マトリックスは 3.1 項に示したと同様の 汎用エポキシ樹脂とした. 解析に使用したマトリックス や口ッドの弹性常数や強度特性は， 3.3 と同様の方法で 求め, Table 3 に示した.

弾性常数の異方性の計算結果を Fig.7 に, 初期破断強 さのそれを Fig.8 に示す.

\section{5. 考察}

三次元多軸複合材料で擬等方性材を得ようとすれば, どのような組織が適しているか，また，異方性を生かす にはどのよらな組織がよいかを考察する。

4 節の計算は, 単位要素の形状が立方体 $(x, y, z$ 軸 J向の寸法が同じ）であり，構成する各ロッドの断面積 や $V_{\mathrm{f}}$ が等しいと拈いている. したがって，3，4，6 軸 
Table 3 Elastic constants and strength of the rod and matrix of the multi-axis composites.

\begin{tabular}{|c|c|c|}
\hline & $\begin{array}{l}\text { Elastic } \\
\text { constants } \\
(\mathrm{GPa})\end{array}$ & $\begin{array}{l}\text { Strength } \\
\text { (MPa) }\end{array}$ \\
\hline \multirow[t]{2}{*}{ Matrix } & $E=3.4$ & tensile strength $=91$ \\
\hline & $\nu=0.38$ & shear strength $=53$ \\
\hline \multirow[t]{2}{*}{ Rod } & $E_{x}=155$ & $\begin{array}{l}\text { axial tens. strength } \\
=1500\end{array}$ \\
\hline & $E_{y}=E_{z}=10.5$ & $\begin{array}{r}\text { comp. strength } \\
=1509\end{array}$ \\
\hline \multirow[t]{4}{*}{$\left(V_{\mathrm{f}}=0.70\right)$} & $G_{x y}=G_{z x}=6.0$ & $\begin{array}{l}\text { shear strength } \\
=53\end{array}$ \\
\hline & $G_{y z}=3.6$ & trans. tens. strength $=91$ \\
\hline & $\nu_{x y}=\nu_{z x}=0.33$ & $\begin{array}{l}\text { comp. strength } \\
=91\end{array}$ \\
\hline & $\nu y z=0.46$ & $\begin{array}{l}\text { shear strength } \\
=53\end{array}$ \\
\hline
\end{tabular}

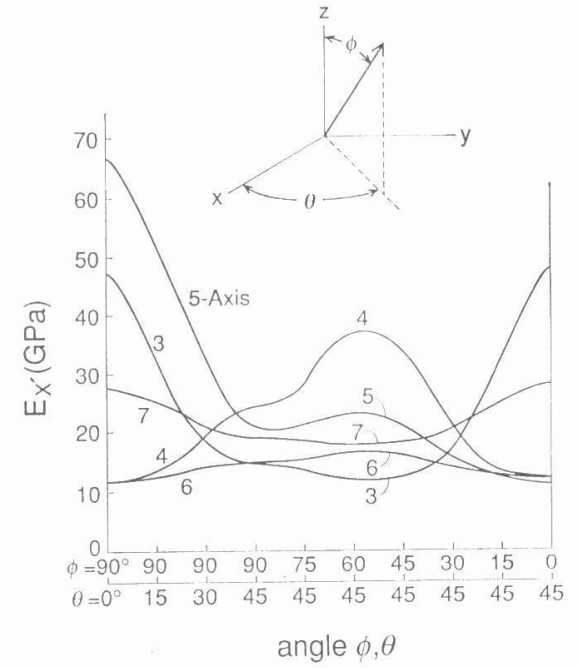

Fig.7 Elastic modulus of 3-D multi-axis composites.

では, 単位要素の $x, y, z$ 軸方向の寸法比を变えたり, 口ッドの断面積や $V_{\mathrm{f}}$ を変劣ると組織の対称性が失われ ることになり，Fig.7 や Fig. 8 の結果以上に異方性を等 方化することはできない，5軸は $x$ 万向のロッドを細く したり $V_{\mathrm{f}}$ を小さくすることで等方化に向からが，yと $z$ 方向に繊維が存在しないので等方化には限界がある. 7 軸は Fig.7 で負荷方向が斜交ロッドの方向である $\theta=$ $45^{\circ}, \phi=54.7^{\circ}$ 方向の特性が低いことから, 斜交ロッド の断面積を直交ロッドより大きくとれば等方化がはかれ

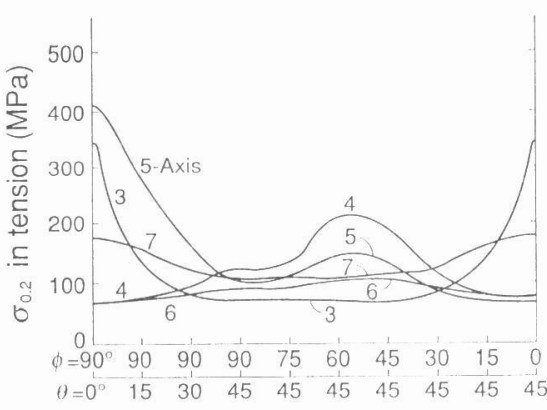

angle $\phi, \theta$

Fig. 8 Initial breaking strength of 3-D multiaxis composites.

ることがわかる，以上から，三次元に擬等方性の複合材 料の組織は, 7 軸が最適であると結論できる.

一力, 異方性の観点で見ると, 検討の対象とした組織 の範囲では, $x$ 軸方问 (Fig.7 の $\theta=0^{\circ}, \phi=90^{\circ}$ ) の特 性が最も大きいのは 5 軸である。また，斜め才向（Fig. 7 の $\left.\theta=45^{\circ}, \phi=54.7^{\circ}\right)$ の特性の大きいのは 4 軸であ る.このことは, 三次元複合材料で異方性を生かした組 織を得よらとすれば， 4 軸か 5 軸，または，それらの併 用が有効であることを示唆している。

\section{6. 結 言}

複数の繊維束を三次元的に配列した複合材料の弾性常 数と初期破断強さの解析方法を, 直交異方性弾性論をも とに導いた，そのさい，単位要素のひずみエネルギーと 単位要素内の各權成部材のひずみエネルギーの総和が等 しいとし, かつ, 単位要素のひずみと各構成部材のひず みが等しいと仮定した。 直交 3 軸複合材料について, こ の解析結果と試験結果を比較した結果, 解析方法が実用 的な精度を有していると判断された。

この方法により，3〜7 軸複合材料の特性の異方性を 求め, 擬等方性材を得るには 7 軸が, また, 異方性の特 長を生かすには 4 軸，5軸が有利であることを指摘 L た.

な抏, 本解析法の妥当性の詳細な検討には, ロッド単 体での弾性常数や強度の測定，および，4 軸以上の複合 材料による試験との対比が望まれるが，今後の課題とす る.

\section{参考文 献}

1) 福多健二（牧廣）：次世代複合材料ハンドプ ック，日本規格協会，東京 (1990), pp. 134-150.

2) T.W. Chou \& F.K. Ko: Textile Structural 
Composites, Elsevier, Amsterdam (1989), p. 129.

3) J. Aboudi : Fiber Sci. Technol., 21 (1984), 277293.

4）八田博志：日本複合材料学会誌，14，2（1988), 73-80.

5）青木栄次, 長塚惟宏, 多田義雄, 福多健二, 穴原 明司, 村山邦彦: 㵶維高分子材料研究所研究報告,
163 (1990.9), 9-12.

6) Z. Hashin : J. Appl. Mech., 46 (1979), 543-550.

7) S.W. Tsai : Composites Design, (4th Ed.), Think Composites, Dayton (1987), pp. 10.910. 11.

8) 土方明躬, 福多健二：日本複合材料学会誌, 18 , 6 (1992), 231-238. 